\title{
Iron Absorption from Infant Foods
}

\author{
SAMUEL J. FOMON, EKHARD E. ZIEGLER, RONALD R. ROGERS, STEVEN E. NELSON, \\ BARBARA B. EDWARDS, DAVID G. GUY, JOHN C. ERVE, AND MORTEZA JANGHORBANI \\ Department of Pediatrics, College of Medicine, University of Iowa, Iowa City, Iowa 52242; Department of \\ Medicine, University of Chicago, Chicago, Illinois 60637; and Mead Johnson Nutritional Division,
} Evansville, Indiana 47721

\begin{abstract}
To determine the bioavailability of iron from iron-fortified infant foods, we have determined erythrocyte incorporation of the stable isotope, ${ }^{58} \mathrm{Fe}$, after feeding the following foods extrinsically labeled with $\left.{ }^{58} \mathrm{Fe}: 1\right)$ rice cereal with apples and bananas ("cereal-fruit product"), 2) Mead Johnson Enriched Baby Food (MJEBF), a vitamin, mineral, and protein-enriched rice cereal, 3 ) vegetables and beef ("vegetable-beef product"), 4) grapejuice, and 5) MJEBF. Foods 1-4 were fortified with ferrous sulfate, and food 5 was fortified with ferrous fumarate. Blood was obtained at ages 140, 168, and $196 \mathrm{~d}$ of age, and the test meal was fed under standardized conditions at $154 \mathrm{~d}$ of age. Erythrocyte incorporation of the ${ }^{58} \mathrm{Fe}$ label was determined from the increase in the mass isotope ratio, ${ }^{58} \mathrm{Fe} /$ ${ }^{57} \mathrm{Fe}$, from the baseline value (at $140 \mathrm{~d}$ of age) to the followup values. The mass isotope ratio was determined by inductively coupled mass spectrometry. Geometric mean total iron incorporation into erythrocytes from the test meal of MJEBF fortified with ferrous sulfate (food 2) was $0.05 \mathrm{mg}$, and from the vegetable-beef product test meal (food 3) was $0.08 \mathrm{mg}$. The low value for MJEBF is presumably explained by the low level of iron fortification. The low value for the vegetable-beef product may reflect the presence of inhibitors of iron absorption. Geometric mean erythrocyte incorporations of iron from the test meals with foods 1,4 and 5 were $0.15,0.14$, and $0.18 \mathrm{mg}$, respectively. These erythrocyte incorporation values are 20 to $26 \%$ of the estimated $0.7 \mathrm{mg}$ requirement for absorbed iron, and therefore seem nutritionally important. (Pediatr Res 26: 250-254, 1989)
\end{abstract}

\section{Abbreviation}

MJEBF, Mead Johnson Enriched Baby Food

Iron deficiency in infancy and early childhood results in large measure from failure to meet the needs for absorbed ironestimated to be 0.7 to $0.8 \mathrm{mg} /$ day $(1,2)$. Because knowledge of iron intake without knowledge of the bioavailability of the iron is of little value, development of a sound approach to establishing strategies for meeting the infant's needs for absorbed iron requires knowledge of the bioavailability of iron in various infant foods.

The iron of human milk, although believed to be remarkably well absorbed, is insufficient to meet the needs of the infant during the latter part of the first year of life (3-5). The infant

Received February 16, 1989; accepted April 26, 1989.

Correspondence Samuel J. Fomon, M.D., Department of Pediatrics, College of Medicine, University of Iowa, Iowa City, IA 52242.

Supported by USPHS HD 07578, AM 34964 and RR 59, DK 26678 and by grants from Mead Johnson Company, H.J. Heinz Company, and Beech-Nut Inc. therefore requires iron in the form of medicinal iron or foods that provide an adequate form and amount of iron. Both direct $(4,6)$ and indirect (7-9) evidence indicates that infants fed ironfortified formulas maintain good iron nutritional status; however, many infants are no longer fed formulas during the latter part of the first year of life and would benefit from foods that provide an adequate form and amount of iron.

Infant foods currently fortified with iron include dry cereals, wet-pack cereal-fruit products, and grape juice. We determined iron absorption from products in these categories. Technical problems prevent fortification of dry cereals with ferrous sulfate or most other iron salts known to be of good bioavailability (10). Currently, these products are fortified with electrolytic iron powder of questionable bioavailability (11). Moreover, cereals contain inhibitors of iron absorption and might not be the most appropriate foods for fortification. To determine whether inhibitors of iron absorption present in infant cereals (fiber and phytate) are likely to be an overriding problem in use of cereals as a vehicle for iron administration, we studied dry cereal fortified with ferrous sulfate. Because absorption of ferrous sulfate iron was found to be quite good, we studied absorption of ferrous fumarate-an iron salt that might be feasible to use for cereal fortification (10).

We also studied absorption of iron from a wet-pack cerealfruit product fortified with ferrous sulfate, and from a vegetablemeat product fortified with ferrous sulfate.

To avoid the administration of radioisotopes to normal infants, we have used the least abundant stable isotope of iron, ${ }^{58} \mathrm{Fe}$ (natural abundance $0.322 \mathrm{wt} \%$ ), and have judged relative bioavailability from erythrocyte incorporation of the isotope $14 \mathrm{~d}$ after administration. Analyses of blood for ${ }^{58} \mathrm{Fe}$ were carried out by inductively coupled plasma mass spectrometry (12). We have demonstrated the feasibility of using ${ }^{58} \mathrm{Fe}$ for studies of iron absorption from meals (13).

\section{MATERIALS AND METHODS}

Normal infants, eight to 12 per feeding group, were given a test meal under standardized conditions at $154 \pm 4 \mathrm{~d}$. All observations reported in the text were made within $4 \mathrm{~d}$ of the stated ages $(140,154,168$, or $196 \mathrm{~d})$. The test meal contained a precisely weighed quantity of approximately $0.85 \mathrm{mg}$ of ${ }^{58} \mathrm{Fe}$. Relative bioavailaibility of iron from the test meals was evaluated by determining ${ }^{58} \mathrm{Fe}$ enrichment of erythrocytes 14 and $42 \mathrm{~d}$ after consumption of the test meal.

Subjects and feedings. The proposal for the study was reviewed and approved by the University of Iowa Committee on Research Involving Human Subjects. Infants who had been subjects for other studies in our unit were enrolled in the studies described here at $112 \mathrm{~d}$ of age. From soon after birth until $112 \mathrm{~d}$ of age, the infants had been fed milk-based or isolated soy protein-based infant formulas providing no less than $1.8 \mathrm{mg}$ of iron/100 kcal. From $112 \mathrm{~d}$ of age until $4 \mathrm{~d}$ after the day on which the test meal 
was fed, the infants were fed a milk-based formula (Enfamil, Mead Johnson Company) providing approximately $0.3 \mathrm{mg}$ of iron $/ 100 \mathrm{kcal}$. Thereafter, the infants were fed a milk-based formula (Enfamil with iron) that provided no less than $1.8 \mathrm{mg}$ of iron $/ 100 \mathrm{kcal}$.

Beikost (foods other than milk or formula) was not fed before $140 \mathrm{~d}$ of age. At $140 \mathrm{~d}$ of age, a food similar to that scheduled for use as the test meal was introduced and fed at least once daily. Then $4 \mathrm{~d}$ after consuming the test meal, the infants were permitted to receive other commercially prepared strained infant foods.

Test meals. The composition of the five test meals is presented in Table 1. The various foods are referred to as follows: food 1 , cereal-fruit product; food 2 with ferrous sulfate, MJEBF fed with ferrous sulfate; food 3 , the vegetable-beef product; food 4, grape juice; food 5 with ferrous fumarate, MJEBF fed with ferrous fumarate. At $154 \mathrm{~d}$ of age each infant visited the Lora $\mathrm{N}$. Thomas Infant Metabolism Unit and was given the test meal midmorning, approximately $2 \mathrm{~h}$ after and $2 \mathrm{~h}$ before a formula feeding. Each test meal contained a precisely weighed amount (about 1 g) of a solution of ${ }^{58} \mathrm{Fe}$-enriched ferrous sulfate, or, in the case of MJEBF fed with ferrous fumarate (food 5), a precisely weighed amount (about $14 \mathrm{mg}$ ) of a powder providing ${ }^{58} \mathrm{Fe}$-enriched ferrous fumarate. Two solutions of the ${ }^{58} \mathrm{Fe}$-enriched ferrous sulfate were used, one providing 0.998 and the other providing $1.016 \mathrm{mg}$ of iron $/ \mathrm{mL}$. The iron was $85.03 \mathrm{wt} \%{ }^{58} \mathrm{Fe}$. The amount of iron added to the test meals from the solutions ranged from 0.934 to $1.116 \mathrm{mg}$. The amount of iron added with the ferrous fumarate powder ranged from 4.177 to $5.612 \mathrm{mg}$.

The cereal-fruit product (food 1) was similar to a commercially available wet-pack (i.e. marketed in jars) cereal with apples and bananas. As marketed, it provides (label claim) $5.3 \mathrm{mg}$ of iron and $12 \mathrm{mg}$ of ascorbic acid/100 g. It was specially produced for us with $3.6 \mathrm{mg}$ of iron/100 g. The product was fed ad libitum from 140 to $154 \mathrm{~d}$ of age. At age $154 \mathrm{~d}, 1 \mathrm{~g}$ of a solution of ${ }^{58} \mathrm{Fe}$ enriched ferrous sulfate was mixed with $50 \mathrm{~g}$ of the food immediately before it was fed. The ferrous sulfate solution provided 1 $\mathrm{mg}$ of iron and $0.85 \mathrm{mg}$ of ${ }^{58} \mathrm{Fe}$. The test meal provided $2.80 \mathrm{mg}$ of iron (Table 1) and $6 \mathrm{mg}$ (label claim) of ascorbic acid.

The MJEBF (food 2 with ferrous sulfate) was a vitamin, mineral, and protein-fortified rice cereal in dry form, supplied to us in $2.5 \mathrm{oz}$ containers. It required only the addition of water

Table 1. Test meals

\begin{tabular}{|c|c|c|c|c|}
\hline \multirow[b]{2}{*}{ Food } & \multirow[b]{2}{*}{ Description* } & \multicolumn{3}{|c|}{ Test meal } \\
\hline & & $\begin{array}{l}\text { Amount } \\
(\mathrm{g})\end{array}$ & $\begin{array}{l}\text { Iron } \dagger \\
(\mathrm{mg})\end{array}$ & $\begin{array}{c}\text { Ascorbic } \\
\text { acidt } \\
\text { (mg) }\end{array}$ \\
\hline 1 & $\begin{array}{l}\text { Rice cereal with apples and } \\
\text { bananas (cereal-fruit } \\
\text { product) } \S\end{array}$ & 50 & 2.8 & 6 \\
\hline 2 & $\begin{array}{l}\text { Rice cereal with formula } \\
\text { (MJEBF with ferrous } \\
\text { sulfate) }\end{array}$ & 40 & 1.1 & 5 \\
\hline 3 & $\begin{array}{l}\text { Vegetables and beef (vege- } \\
\text { table-beef product) }\end{array}$ & 50 & 3.2 & \\
\hline 4 & Grapejuice (grapejuice) & 86 & 2.8 & 27 \\
\hline 5 & $\begin{array}{l}\text { Rice cereal with formula } \\
\text { (MJEBF with ferrous fu- } \\
\text { marate) }\end{array}$ & 30 & 4.6 & 4 \\
\hline
\end{tabular}

* Foods 1 and 3 were supplied by the H. J. Heinz Co., Pittsburgh, PA; foods 2 and 5 were supplied by Mead Johnson Company, Evansville, IN, and food 4 was supplied by Beech-Nut, Inc., Canajoharie, NY.

$\dagger$ The iron in the test meal included intrinsic iron, fortification iron, if any, and a precisely weighed quantity of ${ }^{58} \mathrm{Fe}$-enriched ferrous sulfate (foods 1-4) or ferrous fumarate (food 5); mean values are labeled.

$\ddagger$ Values for ascorbic acid are label claims.

$\S$ Designations in parentheses are used in text. before feeding. As marketed, it provided (label claim) $28 \mathrm{mg}$ of ascorbic acid and $27 \mathrm{mg}$ of iron (91\% electrolytic iron powder and $9 \%$ ferrous sulfate) $/ 100 \mathrm{~g}$. It was produced for use in our test meals without added iron, and, after dilution with water, provided less than $0.128 \mathrm{mg}$ of iron $/ 100 \mathrm{~g}$. Beginning at $140 \mathrm{~d}$ of age, approximately $30 \mathrm{~cm}^{3}$ (one scoop) of the commercial product was mixed with an equal volume of water and offered to the infant. Most of the infants consumed less than $50 \mathrm{~g}$ of the product as fed. At age $154 \mathrm{~d}, 8 \mathrm{~g}$ of the product prepared without the addition of iron was diluted with $32 \mathrm{~g}$ of water. To this mixture, we added $1 \mathrm{~g}$ of a solution of ${ }^{58} \mathrm{Fe}$-enriched ferrous sulfate, which provided $1 \mathrm{mg}$ of iron, including $0.85 \mathrm{mg}$ of ${ }^{58} \mathrm{Fe}$. The $40 \mathrm{~g}$ test meal provided $1.07 \mathrm{mg}$ of iron and $5 \mathrm{mg}$ (label claim) of ascorbic acid (Table 1).

The vegetable-beef product (food 3) was a wet-pack strained vegetable and beef product similar to the commercially available product except that it was fortified with ferrous sulfate to provide $4.0 \mathrm{mg}$ of iron $/ 100 \mathrm{~g}$. The product was not fortified with ascorbic acid. It will be referred to as the "vegetable-beef product." It was fed ad libitum from 140 to $154 \mathrm{~d}$ of age. At age $154 \mathrm{~d}, 1 \mathrm{~g}$ of a solution of ${ }^{58} \mathrm{Fe}$-enriched ferrous sulfate was mixed with $50 \mathrm{~g}$ of the product immediately before it was fed. The ferrous sulfate solution provided $1 \mathrm{mg}$ of iron, including $0.85 \mathrm{mg}$ of ${ }^{58} \mathrm{Fe}$. The test meal provided $3.22 \mathrm{mg}$ of iron (Table 1 ).

The grape juice (food 4) was a commercially available product that supplies $2.1 \mathrm{mg}$ of iron (from ferrous sulfate) and $31 \mathrm{mg}$ of ascorbic acid $/ 100 \mathrm{~mL}$. The juice was fed ad libitum beginning at $140 \mathrm{~d}$ of age. At age $154 \mathrm{~d}, 1 \mathrm{~g}$ of a solution of ${ }^{58} \mathrm{Fe}$-enriched ferrous sulfate providing $1 \mathrm{mg}$ of iron, including $0.85 \mathrm{mg}$ of ${ }^{58} \mathrm{Fe}$, was added to $30 \mathrm{~mL}$ of grape juice in a feeding bottle and fed to the infant. An additional $30 \mathrm{~mL}$ of the juice was added to the bottle, shaken well, and fed to the infant, and a final $26 \mathrm{~mL}$ of juice was added to the bottle, shaken, and fed. The entire test meal ( $86 \mathrm{~mL}$ of juice with the added ferrous sulfate) provided $2.86 \mathrm{mg}$ of iron and $27 \mathrm{mg}$ (label claim) of ascorbic acid (Table 1)

MJEBF (food 5 with ferrous fumarate) was the same as food 2 except for the different iron salt fed with the test meal. The commercial product was fed ad libitum beginning at $140 \mathrm{~d}$ of age. At age $154 \mathrm{~d}$, about $14.0 \mathrm{mg}$ of ${ }^{58} \mathrm{Fe}$-enriched ferrous fumarate powder providing $0.3263 \mathrm{mg}$ of iron $/ \mathrm{mg}$, including $0.05961 \mathrm{mg}$ of ${ }^{58} \mathrm{Fe}$, was added to $6 \mathrm{~g}$ of the dry cereal product prepared for our study and then mixed with $24 \mathrm{~g}$ of water. The test meal provided $4.56 \mathrm{mg}$ of iron, including $0.826 \mathrm{mg}$ of ${ }^{58} \mathrm{Fe}$, and $4 \mathrm{mg}$ (label claim) of ascorbic acid (Table 1).

The ${ }^{58} \mathrm{Fe}$-ferrous fumarate was prepared by one of us (D.G.G.) as follows: to an $0.5 \mathrm{M}^{58} \mathrm{Fe}$-ferrous sulfate $\left(80 \mathrm{wt} \%{ }^{58} \mathrm{Fe}\right.$ ) solution in $2 \mathrm{~N}$ sulfuric acid was added an amount of unenriched ferrous sulfate sufficient to achieve approximately a 5 to 1 ratio of ${ }^{56} \mathrm{Fe}$ to ${ }^{58} \mathrm{Fe}$. The resulting solution was adjusted to $\mathrm{pH} 2.2$ and heated. A hot $1.1 \mathrm{M}$ disodium fumarate solution was added to achieve a 1.5 to 1 molar ratio of fumarate to iron. The solution was mixed at $94^{\circ} \mathrm{C}$, $\mathrm{pH} 3.5-4.5$, until ferrous fumarate precipitated as a dark orange "rust." Mixing was continued for $20 \mathrm{~h}$ at room temperature. The precipitate was washed three times with distilled water and dried in vacuum to constant weight. All of the sulfate ion was recovered in the pooled supernatant and washings. The final product was $94.2 \%$ ferrous fumarate.

Although we realized that interpretation of the results would be aided by providing closely similar amounts of iron in each of the test meals, several practical considerations led us to vary the intakes. In the case of MJEBF when fed with ferrous sulfate (food 2), our major question was whether inhibitors of iron absorption in infant cereals are so effective in preventing iron absorption that cereal should not be pursued as a vehicle for iron fortification. Because we were uncertain about the extent of ${ }^{58} \mathrm{Fe}$ enrichment that might be achieved in the erythrocytes, and because percentage absorption of iron decreases with increasing intakes (14), we elected to study the food fortified only with the enriched ${ }^{58} \mathrm{Fe}$-ferrous sulfate. Thus, iron intake from the food 2 
Table 2. Erythrocyte incorporation of iron from test meals

\begin{tabular}{|c|c|c|c|c|c|c|c|c|c|c|c|c|c|c|}
\hline \multirow[b]{2}{*}{ Subject } & \multicolumn{4}{|c|}{140 days } & \multicolumn{4}{|c|}{168 days } & \multicolumn{4}{|c|}{196 days } & \multicolumn{2}{|c|}{$\begin{array}{c}\text { Erythrocyte } \\
\text { incorporation* }\end{array}$} \\
\hline & $\begin{array}{l}\text { Wt } \\
(\mathrm{g})\end{array}$ & $\begin{array}{c}\mathrm{Hb} \\
(\mathrm{g} / \mathrm{dL})\end{array}$ & $\begin{array}{c}\text { Ferritin } \\
\text { (ng/ } \\
\text { mL) }\end{array}$ & $\begin{array}{c}\text { Mass } \\
\text { isotope } \\
\text { ratio }\end{array}$ & $\begin{array}{l}\text { Wt } \\
(\mathrm{g})\end{array}$ & $\begin{array}{c}\mathrm{Hb} \\
(\mathrm{g} / \mathrm{dL})\end{array}$ & $\begin{array}{c}\text { Ferritin } \\
\text { (ng/ } \\
\text { mL) }\end{array}$ & $\begin{array}{c}\text { Mass } \\
\text { isotope } \\
\text { ratio }\end{array}$ & $\begin{array}{l}\text { Wt } \\
(\mathrm{g})\end{array}$ & $\begin{array}{c}\mathrm{Hb} \\
(\mathrm{g} / \mathrm{dL})\end{array}$ & $\begin{array}{c}\text { Ferritin } \\
\text { (ng/ } \\
\text { mL) }\end{array}$ & $\begin{array}{c}\text { Mass } \\
\text { isotope } \\
\text { ratio }\end{array}$ & $\%$ of Label & Total $(\mu \mathrm{g}) \dagger$ \\
\hline \multicolumn{15}{|l|}{ Food 1} \\
\hline 3688 & 6370 & 10.5 & 20 & 0.1473 & 6830 & 10.3 & & 0.1547 & 7300 & 10.6 & & 0.1533 & 2.7 & 77 \\
\hline 3690 & 7010 & 10.7 & & 0.1483 & 7455 & 12.0 & 30 & 0.1627 & 8050 & 12.0 & 26 & 0.1606 & 6.6 & 191 \\
\hline 3692 & 6025 & 10.8 & & 0.1500 & 6510 & 11.2 & 50 & 0.1571 & 7000 & 11.4 & 36 & 0.1585 & 3.2 & 92 \\
\hline 3693 & 5675 & 11.8 & & 0.1478 & 5755 & 12.2 & 130 & 0.1561 & & & & & 3.2 & 92 \\
\hline 3718 & 5750 & 12.1 & & 0.1455 & 6360 & 11.7 & 90 & 0.1544 & 6710 & 12.3 & 30 & 0.1552 & 3.9 & 113 \\
\hline 3720 & 8550 & 11.7 & 94 & 0.1501 & 8910 & 12.2 & 84 & 0.1561 & 9875 & 10.5 & 55 & 0.1572 & 4.2 & 116 \\
\hline 3740 & 8000 & 10.7 & 29 & 0.1495 , & 8660 & 12.2 & 28 & 0.1720 & 8920 & 11.8 & & 0.1686 & 12.2 & 344 \\
\hline 3741 & 6565 & 9.9 & 31 & 0.1503 & 6800 & 10.6 & & 0.1706 & 7500 & 11.8 & & 0.1694 & 8.2 & 237 \\
\hline 3744 & 7365 & 10.8 & 13 & 0.1493 & 7745 & & & 0.1659 & 8225 & 10.4 & 46 & 0.1731 & 11.4 & 321 \\
\hline 3748 & 8000 & & & 0.1459 & 8110 & & & & 8660 & 12.7 & & 0.1706 & 15.4 & 436 \\
\hline 3772 & 7150 & 11.6 & 61 & 0.1473 & 7565 & 12.1 & 80 & 0.1547 & 7945 & 11.9 & & 0.1533 & 3.4 & 98 \\
\hline 3775 & 5945 & 12.7 & 73 & 0.1490 & 6545 & 12.8 & 82 & 0.1533 & 6775 & 14.0 & 52 & 0.1574 & 3.3 & 92 \\
\hline Mean & 6867 & 11.2 & 46 & 0.1484 & 7270 & 11.7 & 72 & 0.1598 & 7905 & 11.8 & 41 & 0.1616 & 5.4 & 153 \\
\hline \multirow[t]{2}{*}{$\mathrm{SD}$} & 968 & 0.8 & 30 & 0.0016 & 968 & 0.8 & 34 & 0.0068 & 983 & 1.1 & 12 & 0.0074 & 2.9 & 83 \\
\hline & & & & & & & & & & & & & 10.0 & 283 \\
\hline \multicolumn{15}{|l|}{ Food 2} \\
\hline 3700 & 6735 & 11.4 & 40 & 0.1471 & 7230 & 11.7 & 35 & 0.1532 & 7705 & 11.7 & 26 & 0.1564 & 3.7 & 41 \\
\hline 3701 & 7000 & 11.9 & 83 & 0.1518 & 7445 & 11.8 & 100 & 0.1535 & 7715 & 10.3 & 113 & 0.1527 & 0.6 & 6 \\
\hline 3702 & 6900 & 11.3 & 53 & 0.1472 & 7315 & 11.8 & 41 & 0.1676 & 7620 & & & & 9.2 & 107 \\
\hline 3725 & 8000 & 11.6 & 102 & 0.1479 & 8350 & 12.7 & & 0.1580 & 8780 & 12.1 & 33 & 0.1646 & 7.9 & 86 \\
\hline 3726 & 8075 & 11.8 & 138 & 0.1461 & 8425 & 12.0 & 138 & 0.1594 & 8975 & 11.4 & 190 & 0.1574 & 6.7 & 77 \\
\hline 3727 & 7590 & 11.0 & 44 & 0.1486 & 8175 & 11.4 & 51 & 0.1554 & 8735 & 11.0 & 38 & 0.1522 & 2.6 & 29 \\
\hline 3799 & 6355 & 11.3 & & 0.1462 & 6775 & 11.6 & 16 & 0.1565 & 7275 & 11.2 & 18 & 0.1555 & 4.1 & 48 \\
\hline 3862 & 7245 & 12.1 & 13 & 0.1502 & 8015 & 12.8 & 14 & 0.1810 & 8485 & 12.1 & 22 & 0.1884 & 19.0 & 211 \\
\hline 3863 & 6390 & & & & 6875 & 11.4 & 86 & 0.1509 & 7500 & 11.3 & 35 & 0.1525 & 3.0 & 34 \\
\hline Mean & 7143 & 11.5 & 68 & 0.1481 & 7623 & 11.9 & 60 & 0.1595 & 8088 & 11.4 & 59 & 0.1600 & 4.4 & 50 \\
\hline \multirow[t]{2}{*}{$\mathrm{SD}$} & 637 & 0.4 & 43 & 0.0020 & 631 & 0.5 & 44 & 0.0094 & 647 & 0.6 & 61 & 0.0122 & 1.6 & 19 \\
\hline & & & & & & & & & & & & & 11.9 & 134 \\
\hline \multicolumn{15}{|l|}{ Food 3} \\
\hline 3523 & 7375 & 12.0 & 65 & 0.1460 & 7910 & 12.4 & 64 & 0.1505 & 8035 & 11.9 & 110 & 0.1510 & 2.5 & 82 \\
\hline 3803 & 7160 & 9.8 & 62 & 0.1464 & 7750 & 10.7 & & 0.1509 & 8060 & 11.2 & 50 & 0.1517 & 2.6 & 81 \\
\hline 3804 & 6995 & 13.4 & 90 & 0.1468 & 7285 & 12.7 & 100 & 0.1456 & 7640 & 12.9 & 87 & 0.1494 & 0.4 & 13 \\
\hline 3806 & 7775 & 12.7 & 41 & 0.1469 & 8195 & 12.8 & 45 & 0.1545 & 8615 & 12.9 & 50 & 0.1548 & 4.7 & 152 \\
\hline 3807 & 6765 & 13.4 & & 0.1473 & 7485 & 14.1 & 46 & 0.1533 & 7765 & & & & 3.6 & 116 \\
\hline 3865 & 6660 & 11.5 & & 0.1462 & 6975 & 12.1 & 60 & 0.1532 & 7305 & 11.0 & 48 & 0.1542 & 3.5 & 112 \\
\hline 3866 & 6775 & 11.3 & 70 & 0.1467 & 6880 & 11.0 & 57 & 0.1546 & 7575 & 11.2 & 80 & 0.1541 & 3.3 & 109 \\
\hline 3867 & 7825 & 11.1 & 90 & 0.1466 & 8260 & 10.6 & 71 & 0.1541 & 8795 & & & & 3.6 & 118 \\
\hline 3868 & 7525 & 12.3 & 145 & 0.1470 & 8010 & 12.0 & 165 & 0.1481 & 8370 & 12.4 & & 0.1495 & 1.0 & 33 \\
\hline 3869 & 6630 & & & & 7355 & 11.9 & 46 & 0.1551 & 7240 & 11.3 & & 0.1545 & 4.2 & 135 \\
\hline Mean & 7149 & 11.9 & 80 & 0.1467 & 7611 & 12.0 & 73 & 0.1520 & 7940 & 11.8 & 71 & 0.1524 & 2.5 & 80 \\
\hline \multirow[t]{2}{*}{$\mathrm{SD}$} & 455 & 1.2 & 33 & 0.0004 & 490 & 1.1 & 39 & 0.0032 & 531 & 0.8 & 26 & 0.0023 & 1.2 & 37 \\
\hline & & & & & & & & & & & & & 5.3 & 169 \\
\hline \multicolumn{15}{|l|}{ Food 4} \\
\hline 3697 & 6125 & 11.5 & 50 & 0.1491 & 6455 & 12.1 & 39 & 0.1569 & 6850 & 11.4 & 56 & 0.1585 & 3.9 & 109 \\
\hline 3721 & 6095 & 11.1 & 60 & 0.1500 & 6725 & 11.8 & 62 & 0.1660 & 7180 & 11.1 & 62 & 0.1616 & 6.1 & 172 \\
\hline 3723 & 6715 & 11.3 & 42 & 0.1510 & 7575 & 11.8 & & 0.1551 & 7650 & 11.7 & & 0.1522 & 1.2 & 35 \\
\hline 3749 & 6945 & 12.3 & 56 & 0.1444 & 7555 & 12.3 & 98 & 0.1728 & 7810 & 11.4 & 110 & 0.1643 & 12.5 & 357 \\
\hline 3750 & 7865 & 11.9 & 18 & 0.1467 & 8025 & 12.2 & 37 & 0.1523 & 8420 & 12.1 & 22 & 0.1492 & 2.3 & 65 \\
\hline 3827 & 7345 & 12.0 & & 0.1497 & 7700 & 12.3 & 34 & 0.1701 & 8295 & 11.1 & 44 & 0.1705 & 11.2 & 312 \\
\hline 3831 & 7685 & 10.8 & 52 & 0.1456 & 8000 & 11.1 & 46 & 0.1656 & 8470 & 11.5 & 24 & 0.1593 & 8.7 & 249 \\
\hline 3832 & 8675 & 12.3 & 140 & 0.1504 & 9505 & 11.9 & 28 & 0.1533 & 9615 & 12.4 & 56 & 0.1532 & 1.7 & 50 \\
\hline 3856 & 7785 & 11.9 & 50 & 0.1502 & 8310 & 11.9 & & 0.1708 & 8580 & 12.1 & & 0.1714 & 11.0 & 320 \\
\hline 3859 & 8155 & 12.6 & 250 & 0.1460 & 8945 & 12.6 & 46 & 0.1517 & 9455 & 12.5 & 50 & 0.1545 & 4.5 & 129 \\
\hline Mean & 7339 & 11.8 & 80 & 0.1483 & 7880 & 12.0 & 49 & 0.1615 & 8233 & 11.7 & 53 & 0.1595 & 4.8 & 138 \\
\hline $\mathrm{SD}$ & 857 & 0.6 & 72 & 0.0024 & 918 & 0.4 & 22 & 0.0084 & 892 & 0.5 & 27 & 0.0076 & 2.1 & 60 \\
\hline & & & & & & & & & & & & & 11.1 & 316 \\
\hline
\end{tabular}


Table 2. Continued

\begin{tabular}{|c|c|c|c|c|c|c|c|c|c|c|c|c|c|c|}
\hline \multirow[b]{2}{*}{ Subject } & \multicolumn{4}{|c|}{140 days } & \multicolumn{4}{|c|}{168 days } & \multicolumn{4}{|c|}{196 days } & \multicolumn{2}{|c|}{$\begin{array}{l}\text { Erythrocyte } \\
\text { incorporation* }\end{array}$} \\
\hline & $\begin{array}{l}\text { Wt } \\
(\mathrm{g})\end{array}$ & $\begin{array}{c}\mathrm{Hb} \\
(\mathrm{g} / \mathrm{dL})\end{array}$ & $\begin{array}{c}\text { Ferritin } \\
\text { (ng/ } \\
\text { mL) }\end{array}$ & $\begin{array}{l}\text { Mass } \\
\text { isotope } \\
\text { ratio }\end{array}$ & $\begin{array}{l}W t \\
(g)\end{array}$ & $\begin{array}{c}\mathrm{Hb} \\
(\mathrm{g} / \mathrm{dL})\end{array}$ & $\begin{array}{l}\text { Ferritin } \\
\text { (ng/ } \\
\text { mL) }\end{array}$ & $\begin{array}{l}\text { Mass } \\
\text { isotope } \\
\text { ratio }\end{array}$ & $\begin{array}{l}\text { Wt } \\
(\mathrm{g})\end{array}$ & $\begin{array}{c}\mathrm{Hb} \\
(\mathrm{g} / \mathrm{dL})\end{array}$ & $\begin{array}{c}\text { Ferritin } \\
\text { (ng/ } \\
\text { mL) }\end{array}$ & $\begin{array}{l}\text { Mass } \\
\text { isotope } \\
\text { ratio }\end{array}$ & $\%$ of Label & Total $(\mu \mathrm{g}) \dagger$ \\
\hline \multicolumn{15}{|l|}{ Food 5} \\
\hline 3808 & 5760 & 11.1 & & 0.1473 & 6135 & 11.7 & 39 & 0.1546 & 6490 & 12.2 & & 0.1548 & 3.4 & 152 \\
\hline 3810 & 6025 & 12.1 & & 0.1470 & 6315 & & & 0.1522 & 6655 & 12.6 & 64 & 0.1524 & 2.9 & 124 \\
\hline 3873 & 7805 & 11.8 & 50 & 0.1480 & 8290 & 11.7 & & 0.1608 & 8725 & 12.6 & 29 & 0.1604 & 7.8 & 353 \\
\hline 3874 & 8410 & 11.6 & 125 & 0.1474 & 8650 & 12.1 & 125 & 0.1522 & 9325 & 12.0 & 114 & 0.1525 & 2.6 & 146 \\
\hline 3875 & 8270 & 13.5 & 111 & 0.1477 & 8950 & 12.4 & & 0.1526 & 9110 & 12.4 & 84 & 0.1530 & 3.4 & 155 \\
\hline 3877 & 6690 & 12.1 & 61 & 0.1478 & 7045 & 12.5 & 50 & 0.1595 & 7190 & 12.0 & 74 & 0.1594 & 6.4 & 276 \\
\hline 3879 & 6185 & 11.8 & & 0.1485 & 6560 & 11.0 & & 0.1642 & 6885 & 11.4 & 70 & 0.1647 & 7.3 & 325 \\
\hline 3883 & 7550 & 11.7 & & 0.1480 & 7660 & 11.6 & & 0.1515 & 8075 & 12.2 & 110 & 0.1517 & 2.1 & 92 \\
\hline 3898 & 5910 & 12.4 & & 0.1476 & 6405 & 12.2 & 74 & 0.1563 & 7345 & 12.0 & 31 & 0.1561 & 4.4 & 194 \\
\hline Mean & 6956 & 12.0 & 87 & 0.1477 & 7334 & 11.9 & 72 & 0.1560 & 7756 & 12.2 & 72 & 0.1561 & 4.0 & 184 \\
\hline $\mathrm{SD}$ & 1059 & 0.7 & 37 & 0.0004 & 1083 & 0.5 & 38 & 0.0045 & 1084 & 0.4 & 32 & 0.0045 & 2.5 & 116 \\
\hline & & & & & & & & & & & & & 6.5 & 290 \\
\hline
\end{tabular}

* Means for erythrocyte incorporation are geometric means with $\pm 1 \mathrm{SD}$.

$\dagger$ Calculated on the assumption that the percentage incorporation of total iron was identical to the percentage incorporation of ${ }^{58} \mathrm{Fe}$ label.

test meal was less than from the other test meals. Results of our studies with the cereal-fruit product (food 1) and MJEBF with ferrous sulfate (food 2) were available before we studied MJEBF with ferrous fumarate (food 5). However, the concentration of ferrous fumarate in food 5 was determined by the practical consideration that we wished to add at least $0.8 \mathrm{mg}$ of ${ }^{58} \mathrm{Fe}$ to assure a sufficient enrichment of erythrocytes for measurement. This resulted in a larger quantity of iron in the test meal with food 5 than with the other foods.

Procedures. With the exceptions already noted, the infants were managed as described previously (15). Venous blood was obtained at ages 140,168, and $196 \mathrm{~d}$.

Laboratory analyses. Aliquots of the foods were placed in porcelain crucibles, dried at $100^{\circ} \mathrm{C}$, and ashed for $12 \mathrm{~h}$ at $525^{\circ} \mathrm{C}$. The ash was dissolved in nitric acid and the iron concentration was determined by atomic absorption spectrophometry using a Perkin-Elmer model 560 (Perkin-Elmer Corp., Eden Prairie, $\mathrm{MN})$.

$\mathrm{Hb}$ concentration was determined on a Coulter Counter model M430 instrument (Coulter Electronics, Inc., Hialeah, FL). Serum ferritin concentration was determined by radioimmunoassay (catalog no. D-4401, Micromedic Systems, Inc., Horsham, PA). The ${ }^{58} \mathrm{Fe} /{ }^{57} \mathrm{Fe}$ mass isotope ratio $\left(\mathrm{MIR}_{58 / 57}\right)$ was measured by ICP/MS as described previously $(12,15)$.

Calculation of quantity of administered ${ }^{58} \mathrm{Fe}$ label incorporated into erythrocytes. The quantity of administered ${ }^{58} \mathrm{Fe}$ label incorporated into erythrocytes $\left({ }^{58} \mathrm{Fe}_{\text {inc }}\right)$ at a specified time $\mathrm{t}$ after administration of the dose of ${ }^{58} \mathrm{Fe}$ was calculated as follows:

$$
{ }^{58} \mathrm{Fe}_{\text {inc }}=\frac{\mathrm{MIR}_{58 / 57}^{\mathrm{t}}-\mathrm{MIR}^{\circ}{ }_{58 / 57}}{\mathrm{MIR}_{58 / 57}^{\circ}} \times \mathrm{Fe}_{\text {circ }} \times 0.00322
$$

where ${ }^{58} \mathrm{Fe}_{\text {inc }}$ is expressed in $\mathrm{mg}, \mathrm{MIR}^{\mathrm{t}}{ }_{58 / 57}$ is the determined $\mathrm{MIR}_{58 / 57}$ at time $\mathrm{t}$ after dosing, $\mathrm{MIR}^{\circ}{ }_{58 / 57}$ is determined baseline ratio. $\mathrm{Fe}_{\text {circ }}$ is the quantity of total circulating iron $(\mathrm{mg})$ at time $t$, and 0.00322 is the natural abundance (wt fraction) of ${ }^{58} \mathrm{Fe}$.

The quantity of total circulating iron ( $\mathrm{Fe}_{\text {circ }}$, expressed in $\mathrm{mg}$ ) was estimated as follows:

$$
\mathrm{Fe}_{\mathrm{cir}}=\mathrm{BV} \times \mathrm{Hb} \times 3.47
$$

where $\mathrm{BV}$ is blood volume in $\mathrm{mL}$, assumed to be $65 \mathrm{~mL} / \mathrm{kg}$ of body $\mathrm{wt}, \mathrm{Hb}$ is $\mathrm{Hb}$ concentration in $\mathrm{g} / \mathrm{mL}$, and 3.47 is the concentration of iron in $\mathrm{Hb}(\mathrm{mg} / \mathrm{g})$.

${ }^{58} \mathrm{Fe}_{\text {inc }}$ was expressed as a percentage of the administered dose of ${ }^{58} \mathrm{Fe}$. Total erythrocyte iron incorporation was calculated from

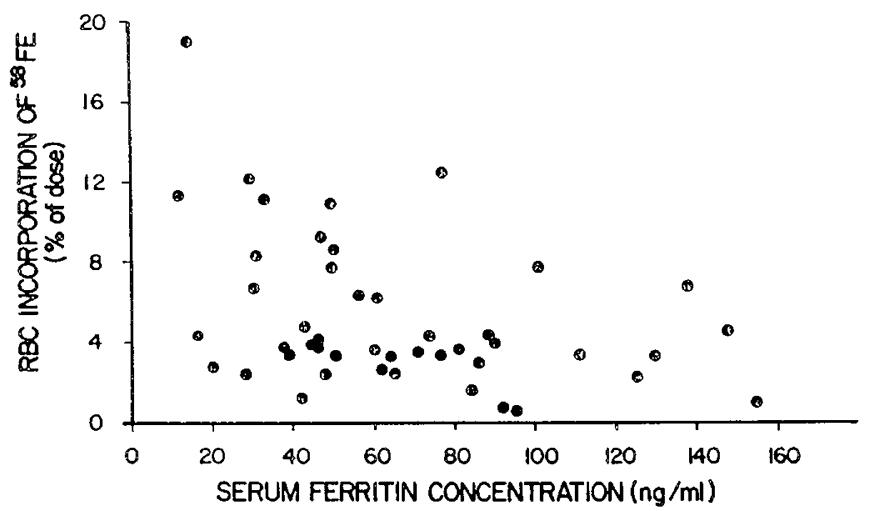

Fig. 1. Erythrocyte (RBC) incorporation of ${ }^{58} \mathrm{Fe}$ (percent of dose) in relation to serum concentration of ferritin (average value for ages 140 and 168 days-see text). Each symbol indicates the RBC incorporation by one infant.

the percentage of the administered ${ }^{58} \mathrm{Fe}$. incorporated times the total amount of iron in the test meal.

\section{RESULTS}

Table 2 presents body wt concentrations of $\mathrm{Hb}$ and ferritin,

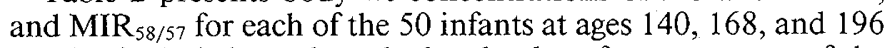
d. Also included are the calculated values for percentage of the administered label incorporated into erythrocytes and the calculated total quantity of iron from the meal incorporated into erythrocytes, assuming that percentage erythrocyte incorporation of the ${ }^{58} \mathrm{Fe}$ label is the same as that of the total iron of the meal.

The values for percentage of administered label incorporated into erythrocytes and for total iron incorporation into erythrocytes are the averages of the results of the calculations for 168 and $196 \mathrm{~d}$. The geometric mean values for percent of administered label incorporated into erythrocytes ranged from $2.5 \%$ for the vegetable-beef product (food 3 ) to $5.4 \%$ for the cereal-fruit product (food 1).

The ${ }^{58} \mathrm{Fe}$ label contributed most of the iron in MJEBF fed with ferrous sulfate (food 2), and 20 to $35 \%$ of the iron in the other foods. However, in studies of absorption of fortification iron, the percentage of the added iron accounted for by the label does not influence the results.

As is evident from Figure 1, erythrocyte incorporation of iron 
(as percent of dose) was inversely related to serum concentration of ferritin $(r=-0.337, p<0.03)$. In most instances, the values for ferritin in Figure 1 are the averages of the concentration at 140 and $168 \mathrm{~d}$; when values were not available for both ages, the value at 140 or $168 \mathrm{~d}$ was used. Subjects for whom neither value was available are not represented in Figure 1. The difference in erythrocyte incorporation of iron from the various foods was not statistically significant (analysis of covariance with serum ferritin as covariate, $p=0.3$ ).

\section{COMMENT}

A number of studies of iron absorption from infant foods have been carried out with the radioisotope, ${ }^{59} \mathrm{Fe}$. Absorption of iron naturally present in human milk has been studied in adults (1618) and infants (19) by use of ${ }^{59} \mathrm{Fe}$ as an extrinsic tag and subsequent whole body counting. Although the results have generally been interpreted (20-22) as indicating that about $50 \%$ of the iron is absorbed, validation of an extrinsic tag for human milk is lacking, and absorption may be much less than $50 \%$.

Iron retention from iron-fortified milks and formulas is influenced by the size of the feeding, the quantity of iron in the feeding (with greater amounts fed, percentage absorption is less), the quantity of ascorbic acid in the feeding and the iron status of the infant. The studies that seem most relevant to usual feeding circumstances are those of Rios et al. (23) and Stekel et al. (24). In each case, the extent of iron absorption was judged by the radioactivity of the erythrocytes $14 \mathrm{~d}$ after consumption of the labeled test meal. With feedings that provided 1.4 to $2.6 \mathrm{mg}$ of iron (from ferrous sulfate) and approximately $6 \mathrm{mg}$ of ascorbic acid in $120 \mathrm{~mL}$ of formula, Rios et al. (23) reported geometric mean absorption by 4 - to 7 -mo-old normal infants to be $4.2 \%$ of the dose.

Stekel et al. (24) studied 5- to 18-mo-old infants, including many with iron deficiency, fed 1.5 to $2.4 \mathrm{mg}$ of iron (from ferrous sulfate) in a test meal of approximately $120 \mathrm{~mL}$. Geometric mean absorptions of iron from six milks or formulas without added ascorbic acid ranged from 2.9 to $5.1 \%$ of the dose. Geometric mean absorptions of iron from five ascorbic acid-containing formulas (approximately 4 to $12 \mathrm{mg}$ of ascorbic acid per test meal) ranged from 5.9 to $11.3 \%$ of the dose. The greater absorptions reported by Stekel et al. (24) than by Rios et al. (23) probably reflect the difference in iron nutritional status of the study groups.

Human studies of iron absorption from beikost (foods other than milk or formula fed to infants) have generally been carried out with adult volunteers. Reports of such studies have been reviewed by Cook and Bothwell (20). Few studies of infants have been reported. Schulz and Smith (25), using radioiron balance, reported a mean value of $9.1 \%$ for absorption of iron from mixed cereal fortified with sodium iron pyrophosphate; however, this value was later questioned (23). Rios et al. (23) determined radioiron absorption from mixed-grain infant cereals by whole body counting of infants $10 \mathrm{~d}$ after administration of the last of five daily test meals labeled with ${ }^{59} \mathrm{Fe}$. The subjects were "4 to 6 mo of age" (apparently more than 4 mo and not yet 7 mo of age). Geometric mean absorption was $0.7 \%$ for ferric orthophosphate (four infants), $1.0 \%$ for sodium iron pyrophosphate (nine infants), $2.7 \%$ for ferrous sulfate ( 25 infants), and $4.0 \%$ for electrolytic iron powder (12 infants). The electrolytic iron powder was of considerably smaller particle size than that used in commercial fortification of infant cereals $(11,23)$. Iron absorption from other infant foods has not been reported.

Geometric mean total iron incorporation into erythrocytes from the test meal of MJEBF fortified with ferrous sulfate (food 2 with ferrous sulfate) was $0.05 \mathrm{mg}$, and from the vegetable-beef product test meal (food 3) was $0.08 \mathrm{mg}$. The low value for MJEBF is presumably explained by the low level of iron fortification. The low value for the vegetable-beef product may reflect the presence of inhibitors of iron absorption. There was certainly no suggestion that the presence of beef enhanced iron absorption.
However, the product provided only about $5 \%$ of solids from beef. We plan in future studies to determine erythrocyte incorporation of ferrous sulfate added to a meat and vegetable product that provides a greater amount of meat. Iron absorption from the iron-fortified grapejuice (food 4) may have been enhanced by the favorable ratio of ascorbic acid to iron.

Geometric mean erythrocyte incorporation of iron from three of the foods (the cereal-fruit product, grape juice, and MJEBF with ferrous fumarate-foods 1,4 , and 5 , respectively) ranged from 0.14 to $0.18 \mathrm{mg}$. These foods and others that may promote as good or better retention of iron seem worthy of further study. Assuming a requirement for absorbed iron of $0.7 \mathrm{mg} /$ day, erythrocyte incorporation of $0.14 \mathrm{mg}$ amounts to $20 \%$ of the requirement for absorbed iron, and $0.18 \mathrm{mg}$ /day amounts to $26 \%$ of the requirement for absorbed iron. These erythrocyte incorporations from meals of quite modest size thus appear to be nutritionally meaningful, particularly because erythrocyte incorporation is unlikely to account for all of the retained iron.

\section{REFERENCES}

1. Fomon SJ 1974 Infant Nutrition, 2nd ed. W B Saunders Co., Philadelphia, p 309

2. Stekel A 1984 Iron requirements in infancy and childhood. In: Stekel A (ed) Iron Nutrition in Infancy and Childhood. Raven Press, New York, pp 1-10

3. Saarinen UM 1978 Need for iron supplementation in infants on prolonged breast feeding. J Pediatr 93:177-180

4. Hertrampf E, Cayazzo M, Pizarro F, Stekel A 1986 Bioavailability of iron in soy-based formula and its effect on iron nutriture in infancy. Pediatrics 78:640-645

5. Fomon SJ 1987 Reflections on infant feeding in the 1970s and 1980s. Am J Clin Nutr 46:171-182

6. Marsh A, Long H, Stierwalt E 1959 Comparative hematologic response to iron fortification of a milk formula for infants. Pediatrics 24:404-412

7. Vazquez-Seoane P, Windom R, Pearson HA 1985 Disappearance of irondeficiency anemia in a high-risk infant population given supplemental iron. N Engl J Med 313:1239-1240

8. Miller V, Swaney S, Deinard A 1985 Impact of the WIC program on the iron status of infants. Pediatrics 75:100-105

9. Anonymous 1986 Declining anemia prevalence among children enrolled in public nutrition and health program selected states, 1975-1985. JAMA $256: 2165$

10. Hurrell RF 1984 Bioavailability of different iron compounds used to fortify formulas and cereals: technological problems. In: Stekel A (ed) Iron Nutrition in Infancy and Childhood. Raven Press, New York, pp 147-178

11. Fomon SJ 1987 Bioavailability of supplemental iron in commercially prepared dry infant cereals. J Pediatr 110;660-661

12. Janghorbani M, Ting BTG, Fomon SJ 1986 Erythrocyte incorporation of ingested stable isotope of iron $\left({ }^{58} \mathrm{Fe}\right)$. Am J Hematol 21:277-288

13. Woodhead JC, Drulis JM, Rogers RR, Ziegler EE, Stumbo PJ, Janghorbani M, Ting BTG, Fomon SJ 1988 Use of the stable isotope, ${ }^{58} \mathrm{Fe}$, for determining availability of nonheme iron in meals. Pediatr Res 23:495-499

14. Bothwell TH, Charlton RW, Cook JD, Finch CA 1979 Iron Metabolism in Man. Blackwell Scientific Publications, Oxford, p 261

15. Fomon SJ, Janghorbani M, Ting BTG, Ziegler EE, Rogers RR, Nelson SE, Ostedgaard LS, Edwards BB 1988 Erythrocyte incorporation of ingested 58iron by infants. Pediatr Res 24:20-24

16. McMillan JA, Landaw SA, Oski FA 1976 Iron sufficiency in breast-fed infants and the availability of iron from human milk. Pediatrics 58:686-691

17. McMillan JA, Oski FA, Lourie G, Tomarelli RM, Landaw SA 1977 Iron absorption from human milk, simulated human milk, and proprietary formulas. Pediatrics 60:896-900

18. Oski FA, Landaw SA 1980 Inhibition of iron absorption from human milk by baby food. Am J Dis Child 134:459-460

19. Saarinen UM, Siimes MA, Dallman PR 1977 Iron absorption in infants: high bioavailability of breast milk iron as indicated by the extrinsic tag method of iron absorption and by the concentration of serum ferritin. J Pediatr 91:36-39

20. Cook JD, Bothwell TH 1984 Availability of iron from infant foods. In: Stekel A (ed) Iron Nutrition in Infancy and Childhood. Raven Press, New York, pp 119-145

21. Lönnerdal B 1984 Iron and breast milk. In: Stekel A (ed) Iron Nutrition in Infancy and Childhood. Raven Press, New York, pp 95-117

22. Lynch S 1984 Iron. In: Solomons NW, Rosenberg IH (eds) Absorption and Malabsorption of Mineral Nutrients. Alan R. Liss, Inc., New York, pp 89124

23. Rios E, Hunter RE, Cook JD, Smith NJ, Finch CA 1975 The absorption of iron as supplements in infant cereal and infant formulas. Pediatrics 55:686693

24. Stekel A, Olivares M, Pizarro F, Chadud P, Lopez I, Amar M 1986 Absorption of fortification iron from milk formulas in infants. Am J Clin Nutr 43:917922

25. Schulz J, Smith NJ 1958 A quantitative study of the absorption of food iron in infants and children. Am J Dis Child 95:109-119 